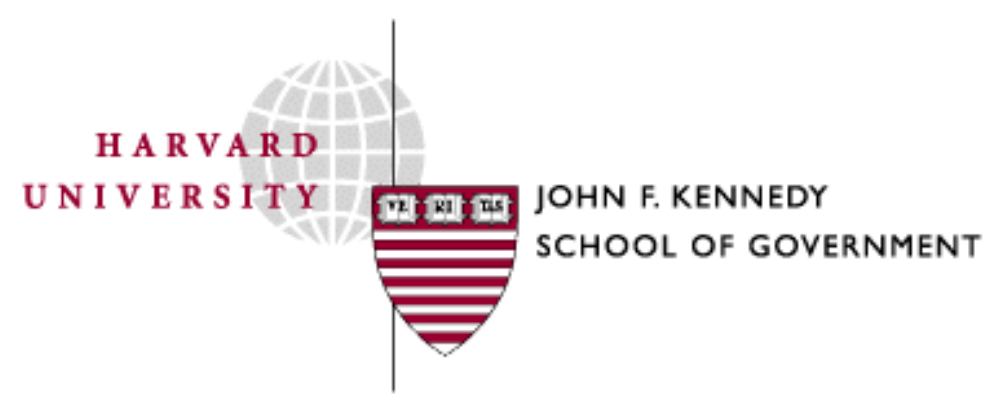

Faculty Research Working Papers Series

\title{
Effective Foundation Boards: The Importance of Roles
}

\author{
Christine Letts
}

October 2005

RWP05-054

The views expressed in the KSG Faculty Research Working Paper Series are those of the author(s) and do not necessarily reflect those of the John F. Kennedy School of Government or Harvard University. Copyright belongs to the author(s). Papers may be downloaded for personal use only. 


\section{Effective Foundation Boards \\ The Importance of Roles \\ by \\ Christine W. Letts}

\section{The Hauser Center for Nonprofit Organizations and \\ The Kennedy School of Government \\ Harvard University}

October 2004

Working Paper No. 26

\section{This paper can be downloaded without charge from the Social Science Research Network Electronic Paper Collection: http://ssrn.com/abstract $=642562$}

Christine W. Letts is the Rita E. Hauser Lecturer in the Practice of Philanthropy and Nonprofit Leadership and Associate Director of the Hauser Center. A version of this paper will be published by the Bertelsmann foundation in 2005.

This paper is not to be reproduced or transferred without the permission of the author. 


\begin{abstract}
Foundations are unique among organizations in the enormous latitude they have in determining their work and the manner in which it is done. This flexibility manifests itself particularly in the variety of roles that foundation board members can take. Most of the literature in the field focuses on best practices in board structure and processes. These are necessary in the spirit of responsiveness and legal accountability, but are not sufficient for effectiveness. Achieving role clarity, influence in decision-making and responsibility for impact are three keys to more effective foundation governance. These three attributes can be better understood and achieved by examining the roles of foundation board members as individuals and as a collective.

Recognizing these important, often overlooked, phenomena will help boards not only have good work that will keep them enthused and committed, but also to produce the good work that the public expects.
\end{abstract}




\section{Effective Foundation Boards \\ The Importance of Roles \\ by}

\section{Christine W. Letts}

\section{Introduction - The Importance of Roles in Effective Governance}

Unlike boards of corporations or typical social service nonprofit organizations, most foundation boards are as unrestricted in their flexibility as they are unfettered by accountability. This makes foundations unique among organizations in the enormous latitude they have in determining their work and the manner in which it is done. One foundation president summed up the distinct nature of foundations as organizations that have "few measures and few imperatives." If we want to create more effective foundations, we need to grapple more directly with the implications of this flexibility. This flexibility manifests itself particularly in the variety of roles that foundation board members can take.

First, flexibility affects accountability. Foundations come into existence when individuals set aside an amount of wealth for charitable purposes. Particularly in the U.S., foundations are frequently endowed in perpetuity. Trusteeship begins with fulfilling the wishes of the benefactor. This means that foundation board members do not have to pass the accountability test presented either to trustees of a nonprofit or of a corporation. The former must continue to raise funds to stay in existence. The latter must assure that both customers and shareholders are well served. Because of the nature of foundation work, providing money or services (in the case of operating foundations) to eager supplicants, they operate in an environment that suppresses feedback. On the one hand, nothing is easier than running a foundation. On the other hand, nothing is harder. It is like trying to play tennis without a net or foul lines.

Second, flexibility affects organizational design. One of the few requirements imposed on all foundations is that they must have a board. Not only is it the ultimate authority for decisionmaking in the foundation, the board may be the only authority. A foundation board either has total freedom to establish the mission and activities of the foundation or wide latitude in interpreting a trust or mission left by the founder. Trustees also have the freedom to establish the 
structure of the entity, including whether to have staff or not. The boards of foundations are likely to be far more influential over the day-to-day operations of a foundation throughout its lifespan than the boards of other types of organizations. Board roles and behavior are affected in predictable and important ways by the different structures and types of foundations. Role differences are most pronounced in three types of foundations:

1. Those in which boards do all of the work

2. Those in which decision-making is divided between board and staff and

3. Those in which the benefactor, in a private foundation, or a CEO, in a corporate foundation, are active and on the board.

After studying and working with dozens of foundations over the past 4 years, I have become convinced that we have been searching for better governance solutions in the wrong places. Most of the literature in the field focuses on best practices in board structure and processes. ${ }^{1}$ Attention to compliance with laws, industry standards and fiduciary duties will continue to intensify given the most recent media and political attention to abuses by foundation leaders and trustees. ${ }^{2}$ The field has worked to develop guidelines for the operation of foundations and their governance, the most notable (and controversial) being the principles established by the Council on Foundations as requirements for membership. As recently as January 2004, the noted philanthropic consultant, Peter Karoff, suggests that foundations undertake customer feedback, peer review and standards in order to regain public trust. ${ }^{3}$ These guidelines are important, but conversations with foundation CEOs and trustees over the last four years indicate to me that they are necessary in the spirit of responsiveness and accountability, but not sufficient for effectiveness. ${ }^{4}$

This "best practice" approach falls short because it does not take into account the "flexibility factor" that challenges foundations. The actual experience of hundreds of foundations tells us that a wide variety of structures and processes can be made to work. Moreover, the prescriptions about structure and processes fail to address the real problems experienced by sitting boards.

\footnotetext{
1 Appendix II

${ }^{2}$ See Fremont-Smith, Marion, "Governing Nonprofit Organizations: Federal and State Law and Regulation"(Belknap Press Copyright 2004)

${ }^{3}$ Karoff, Peter, "On the Issue of Trust," The Philanthropic Initiative, January 2004.

${ }^{4}$ Many of the quotes and examples in this paper come from the Executive Session on the Future of Philanthropy convened by The Hauser Center for Nonprofit Organizations, Harvard University from 1999-2002 and the International Network in Strategic Philanthropy sponsored by the Bertelsmann Foundation from 2002-2004.
} 
In this paper, I will argue that some of the most chronic problems experienced by foundation boards could be addressed if there were greater clarity about the roles that the board can play. In other kinds of organizations, board roles are both well defined and well-aligned with structure and processes. ${ }^{5}$ This is not the case for foundations. Because foundations have far more latitude in how they define and do their work, the role of the Board and of individual board members is far more problematic. Yet it is a problem we have largely overlooked.

In making a case for focus on roles, I am not minimizing the significant challenge foundations have in meeting public expectations - either those explicitly mandated by law or those implicitly set by societal norms. The first obligation of any board of trustees is to know the law and establish compliance with it. In fact, the legal context in which a foundation operates is likely to establish roles, or put limits of some kind on them, for foundation trustees. Nothing in this paper is intended to replace, obscure or undermine this basic responsibility.

\section{Moving Toward Greater Board Effectiveness}

When foundation CEOs and board members describe their problems, they fall naturally into three categories.

Lack of clarity. A common problem is lack of clarity about the roles of board members that includes, if there is staff, lack of clarity about the division of decision-making. There are six major areas for decision-making for a grantmaking foundation: establishing the mission; developing programmatic strategy; establishing the organizational structure and culture; determining grantmaking strategy; determining the guidelines for grantee relationships; and evaluation. Achieving clarity about the role of the board as a collective or the roles of individuals has two components. The first is the ability to articulate the intended role or roles for each foundation board member and the group as a whole. The second component is assuring that these roles are aligned with expectations of the board members and with staff, if there is one.

1. Lack of influence. Even when tasks are consistent with expectations, it may turn out that the board members do not feel as though the work is important, or that they have any

\footnotetext{
${ }^{5}$ Just because there is clarity, it does not mean effectiveness. For a full discussion of the problems of boards of conventional nonprofits, see Governance as Leadership by Richard Chait, William Ryan and Barbara Taylor, BoardSource, forthcoming, 2004.
} 
significant influence over decisions that matter. Therefore, in addition to clarity, the second condition we want to achieve within the board is influence. When either of these two conditions is absent, we would typically find a situation in which one or more of the stakeholders are dissatisfied. This is true for board members in foundations without staff, or for board and staff alike in staffed foundations.

2. Responsibility for impact. While the first two conditions set a minimum standard for "functioning," in that board and staff are happy with the situation, they do not address whether anything of worth is being accomplished. Many foundation leaders agree that boards have accountability for two dimensions of performance: to do the right thing and to do it well. Doing the right thing may mean meeting social needs, usually articulated in the mission (value determined by the outside) or adhering to donor intent (value determined on the inside), or as is frequently the case, both. ${ }^{6}$ The actual question to ask is whether the board is contributing to effectiveness.

I offer two questions that can help a foundation board begin to diagnose its effectiveness:

- Is this board functioning to everyone's satisfaction? This question will help the board identify issues relating to clarity and influence.

- Is the board operating in a way to enable the foundation to maximize its impact? This question helps the board understand its role and responsibility in assuring that the foundation is creating value, and not simply following guidelines associated with its activities or output.

Achieving clarity, influence and responsibility are three keys to more effective foundation governance. They can be better understood and addressed by examining the roles of foundation board members as individuals and collectively. In the following sections, I will identify the roles that foundation board members occupy and discuss the problems that can accompany them. Recognizing these important, but unappreciated phenomena will help boards not only have good work that will keep them enthused and committed, but also to produce the good works that the

\footnotetext{
${ }^{6}$ Letts, Christine, "Foundation Boards: Value, Cost and Questions," unpublished paper, February 2002.
} 
public expects. Appendix I contains a more complete set of questions to help foundation boards achieve satisfaction and effectiveness.

The Question of Accountability to the Public

Are foundations accountable for their activities to the public? This is an issue that is fairly hotly debated among foundation trustees and executives. Some claim that foundations, by virtue of being publicly authorized by tax codes or regulation, and legally bound to provide "public good," must be accountable, in a transparent way, for their activities to the public. Others argue that private foundations carry no such burden, as long as they are obeying the law. Some private foundation trustees will cite that they are only accountable to fulfill the conditions of a founder's trust or will. Executives of foundations where there is still a living donor will cite that they are accountable to the wishes of the donor. There has been no legal interpretation that holds foundations accountable to the public for more than the legal requirements, using the definition "having to report, explain or justify" for accountability.

However, I do think that foundations hold certain ethical obligations, and even where they are not legally accountable, we should hold them responsible for certain acts or behaviors. Acting ethically means using principles to make judgments and decisions. For example, the moral responsibility to "do no harm" is one with which hardly any foundation would disagree, yet many foundation boards have no procedures or processes to assure themselves that in fact they are not causing harm (in the level of cost, for example) to grantees or the public. There is no requirement that a foundation proclaim publicly about the impact and effectiveness of its programs, but if it does, it should tell the truth and be able to defend its claims. This paper offers foundation trustees a set of questions that provide a minimum level of self-examination and assessment and that set the basis for principles on which to operate.

\section{Achieving Clarity and Influence}

The first challenge is to establish the role of the board as a collective, the roles of individuals on the board, and the division of decision-making. The greatest challenge here is not finding the "one right answer" but making sure that the roles are aligned with the expectations of prospective members.

Board members will want to know how they can be important to the foundation. There are a couple of principles that will help board members contribute value. First, minimize the transactional work where neither staff nor board members feel valuable. Spending time does not substitute for influence. Board members will be willing to put up with some redundant or 
perfunctory work that may be necessary, if they have other opportunities to channel their interest or expertise. Second, board members should be encouraged to focus their time and energy committed to the foundation. They may focus on a part of the grant making process, such as helping to do site visits, or they may focus on a subject area, such as the arts, in which the foundation does work. In each of these examples, a board member will become valuable by virtue of his time contribution and the knowledge that he will build about the work of the foundation. Rotating responsibilities from time to time will avoid some of the pitfalls associated with ownership or power-grabbing. Unfortunately, identifying the roles where individuals really add value is easier said than done.

\section{The Evolution of Boards}

Roles on foundation boards are not static. Roles may change as strategy and size change, but the most profound changes may happen from a foundation's inception through the years as it "institutionalizes." The roles and behavior of members of a founding board, who may have had close association with the original donor, will be very different than those of trustees brought on years later for their legitimacy or expertise in a substantive area. A founding foundation CEO observed the following about this evolution, "There is an interesting transition period when a new foundation is set up and the board/donor dominate, and when the foundation becomes more conventional with the staff making most of the decisions and the board sets policy. Getting from $\mathrm{A}$ to $\mathrm{C}$ is not that easy. We had a few board members who really helped with that process, and then weren't entirely overjoyed when the staff didn't always do their bidding anymore!" Thus, the questions that make sense in framing the roles and responsibilities for foundation boards remain relevant throughout a foundation's lifespan and need to be asked regularly.

\section{A pivotal question: Are board members informed givers or institutional trustees?}

Clearly one of the appeals of foundation board work is the opportunity to be generous - to give away money. Self-dealing episodes aside, this spirit of altruism is not bad. It drives the commitment with which most foundation board members tackle their assignment. For board members in foundations with no staff, they have the opportunity to be givers as well as trustees. Many staffed foundations turn to the corporate model for their governance design. As institutional trustees, they establish or interpret the mission, approve strategies and assure that grant making programs are consistent with the mission and strategy. However, the psychology 
of generosity tends to put boards in a peculiar position: they want to be involved in all of the work, rather than maintain the distance of institutional trustees

Lack of clarity about these two fundamental roles is the source of much of the tension for staff and boards alike. One foundation executive said, "It seems to me that it's going to be hard for this sector, for all of us, to have the highest impact that we could have with such ambiguity and uncertainty about how the board, the CEO and the staff all relate to each other." One consultant

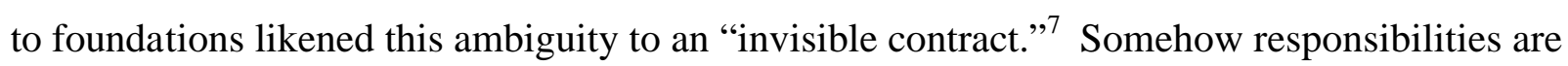
divided up, and sometimes it works and sometimes it doesn't. At worst, there is an ongoing tug of war, with the board and staff spending a lot of time and psychic energy jockeying for position. A large well-known family foundation in New York spent ten years in this condition after the family board hired its first (and current) CEO and program staff. Over the years, the board has moved in and out of each of the aforementioned six decision-making arenas, creating a set of misaligned policies that have certainly caused dissatisfaction and may have constrained the organization's ability to have impact.

\section{The Informed Giver Role}

\section{$\underline{\text { Boards as Staff }}$}

For foundations with little or no staff, which represents $94 \%$ of the total foundations in the U.S. ${ }^{8}$, it is clear that the board does the work, however it is defined. Without staff, the work will normally be restricted to grantmaking, since operating foundations need staff to run activities. The board likely has a lot of latitude in how it does its work, from deciding whether to take proposals to how to divide the work among the members. Although the roles themselves are likely to be fairly clear, the problem may be that the way the work is defined may be neither efficient nor effective.

\footnotetext{
${ }^{7}$ Tom Tierney, Chairman, Bridgespangroup.

${ }^{8}$ Staffed foundations represent $58.2 \%$ of foundation assets. $62.7 \%$ of staffed foundations report only $1-2$ staff. Foundation Today Series 2003 Edition "Foundation Staffing; Foundation Center.
} 
The work of the board may be divided horizontally or vertically. In the horizontal version, the work is assigned by function, such as intake, review, and site visits, with each board member participating in a part of the process to get the grant recommendations to the board. The whole board then makes final decisions on grants. In the vertical version, each board member performs all functions for a program area of grants. Final approval by the entire board is essentially perfunctory, as each board member accepts the others' recommendations.

When board members play the informed giver role, the good news is that it allows them to feel good about making altruistic decisions and act as appropriate stewards of the public trust at the same time. They can fully enjoy the expressive benefit of trusteeship as well as the instrumental. ${ }^{9}$ This means that they can fulfill their own personal philanthropic aspirations or vision, and thus have personal satisfaction, and they have role in creating public value, and have thus fulfilled their institutional responsibility.

However, problems arise when roles are defined that do not achieve an appropriate balance between these two ideals. Here are four symptoms that the board should be on the lookout for:

1. Mission drift. When the work is divided vertically, with each board member managing his or her own portfolio from start to finish, it is difficult for the foundation to maintain a clear and coherent mission. In foundations with very broad missions, where this may not result in a significant departure from the legal mandate, it may lead to a confusing or capricious character. As each board member defers to the others judgment without scrutiny or question, legal oversight responsibility assigned to all members may be shirked. The foundation may drift into a collection of individually motivated charities, without regard to strategy or impact.

2. Unfulfilling work. I met a board member at a conference who complained about his role in the family foundation. The board had divided up the work among the members to “keep all of them involved" but this had unintended consequences. This nephew's

\footnotetext{
${ }^{9}$ For a full discussion of the expressive and instrumental motivation in nonprofits, see Frumkin, Peter, On Being Nonprofit, Harvard University Press, 2003.
} 
responsibility was to open proposals and do a first screening for those that clearly did not meet the foundations guidelines. While this work was essential, and influential, it was drudgery. He had to wade through lots of paperwork and had the privilege of saying "no" to hundreds of proposals. He preferred not to be involved in the foundation at all rather than have this job.

3. More work than expected. Most people consider serving on a foundation board to be an honor and a pleasure, and individuals will usually calculate that the work is worthy of some level of time. Without staff, however, the work can expand beyond what many would consider appropriate volunteer time. Even if the trustees are compensated, the rate may not justify the amount of work. A recent survey in the U.S. found that more than two-thirds of the foundations surveyed pay fees to their trustees. ${ }^{10}$ However, there has been no study that compares the level of compensation to the work. The hazard of too much work is that the work may be compressed to fit the time, which results in lessinformed grantmaking. Moreover, the pool of people willing to serve as trustees may shrink, jeopardizing the quality of decision-making. The Society for Good and Charitable, known as GGG, is a foundation that has been operating in Basel, Switzerland since 1778. A religious-based association (not technically a foundation under Swiss law) it has been operating under the dictum, "the rich do not go to heaven." It provides about 5 million Swiss francs in grants per year. There are seven trustees that perform all the work with the aid of two secretaries. The presidency rotates each year among the seven. Each trustee is in charge of one of seven thematic areas, such as children, elderly, music, art, and they keep each for seven years. The entire board approves all the grants and reviews all denials in meetings held every two weeks. One estimate is that the trustees spend up to $20 \%$ of their time on foundation work, and they are not compensated. While past generations have been satisfied with this arrangement, some younger working men and women find it difficult to spend this amount of time uncompensated.

\footnotetext{
${ }^{10}$ Ahn, Christine, Eisenberg, Pablo, Khamvongsa, Channapha, "Foundation Trustee Fees: Use and Abuse," Georgetown Public Policy Institute, Washington, D.C. 2003.
} 
4. Insularity and shirking institutional trusteeship. In foundations without staff, the mundane work that we all associate with the institutional trustee role, such as paying attention to industry standards or norms, may take a backseat to the board's full plate of grantmaking responsibilities. For example, there are few laws and few legal precedents that help foundation trustees set compensation for themselves. Only the most egregious examples of greed are challenged legally, such as the Bishop Estate in Hawaii, in which the directors received $\$ 1$ million per year. Challenges are more likely to come from the media that arouse some sense of public outrage when it looks like trustees have burst through some hazy boundary of selfishness. In June 2003 The Buffalo News ran an article spotlighting the compensation of the three trustees of the Oishi Foundation in Buffalo, New York, each of whom makes $\$ 127,000 .^{11}$ It turns out that the compensation, which is a percent of assets, is specified in the foundation trust. While the Council on Foundations discourages this policy, the foundation trustees still feel that the compensation is not excessive for the amount of work they perform with no staff. With little accountability for results and virtually no oversight, compensated foundation trustees are likely to be targets for occasional scrutiny. ${ }^{12}$ Having staff does not guarantee that this will not happen, but staff is likely to be more tuned in to industry norms. Excessive private benefit is an example of where trustees abdicate all of their responsibility as institutional trustees.

\section{The Informed Giver Role in Family Foundation Boards}

In many foundations, the original donor is part of the decision-making. This may be the patriarch or matriarch of a family, a wealthy self-made individual or someone who has inherited wealth. If the individual sets up a foundation through which to do his philanthropy, he may be required to have a board, or may want one. Frequently one of the first impulses of a principal is to make philanthropy a family affair. The patriarch may intend for the foundation to be a family

\footnotetext{
${ }^{11}$ Tokasz, Jay, "Givers Under Scrutiny: Charitable Foundations Nationally Gave Nearly $\$ 30$ Billion in 2002, But some in Congress Think They Could Give More, If Less Were Spent on Salaries and Trustee Fees," The Buffalo News, July 11, 2003, A1.

${ }^{12}$ The Boston Globe investigative reporters found one trustee who paid himself several hundred thousand dollars extra in one year to afford an expensive wedding for his daughter. Healy, Beth et al., "Some Officers of Charities Steer Assets to Selves", Boston Globe, October 9, 2003, A1.
} 
legacy, to preserve and protect the family's place in the community. He may want to establish a place and activity where the family works together. He may want to train successive generations to be mindful of the community and learn how to give appropriately. Family boards may at once be the most natural and unnatural bodies. Like royalty, family members arrive on the board because of birth, not because they know anything about philanthropy, the cause, or the community. Their existing relationships may bring great advantage to the workings of the board, but just as easily they may bring great dysfunction.

\section{A pivotal question: Is the board role in a family foundation an obligation or an opportunity?}

Whether the role is an obligation or an opportunity begins to shape all expectations and interactions. There is a big difference between asking children to be trustees of a parent's legacy and giving them the opportunity to become philanthropists. Either one of these can be fine, but clarity about this is important. In this way then, the funder's intentions need to be aligned with the structure and processes developed for the board.

Consider Joe Jacobs, an engineer who became wealthy through his company. He created a foundation in San Diego and asked his three daughters to be on the board. He said that every person had an equal vote. His daughters called his intention into question when he insisted that the foundation make a grant to a conservative think tank. They objected. He ended up backing down, and renewed his commitment to the foundation as a place for the family to make decisions together, where all the voices matter. Each member could give to causes not adopted by the whole group out of their private wealth. This clarification turned out to be healthy and productive for the family and the foundation. ${ }^{13}$

Frequently, no matter what the principal or charter says, the family reverts into long-standing, predictable roles with each other. Despite the best intentions of a patriarch or matriarch, family foundation boards rarely provide a space for family togetherness and harmony if those conditions

\footnotetext{
${ }^{13}$ For more on the Jacobs Family Foundation, see "The Jacobs Family Foundation," Kennedy School of Government Case Program, forthcoming 2004.
} 
do not already exist. Negative family dynamics are just as likely to appear and disrupt the smooth functioning of a foundation board as they are a holiday dinner.

Board dynamics will inevitably change as family circumstances change. Family members marry, divorce, have children, move away, and pass away. There are many reasons that roles, responsibilities and relationships evolve, so it is important to structure processes to allow family boards to adapt. The staff executive of a large, well-known family foundation in New York City reminds us of this by remarking that in a family, the "deals are never done."

\section{A Special Distinction: The Advisor Role}

After family, the principal of a foundation will bring outside people onto the board in the role of advisors. Family boards frequently benefit from outsiders who can serve to mediate or mitigate family conflict, which is why someone who already has a relationship with the family can be valuable. These people are trusted friends or colleagues, and may be lawyers or investment advisors. The nature of the relationship usually sets the expectations about role; in that they understand that they are there as an aide to the principal decision-maker, rather than as an institutional trustee, although they may carry the latter role legally. For example, A wealthy businessman from Texas, Bob Buford, started a foundation and organized a board of "smart people who help him think."

Board roles in corporate foundations may be similar to those in private foundations with a living donor because of the presence of the top executive to whom other executives or outsiders look for final decisions. The executive will usually wield informal leadership if not formal leadership as a board chair. So a normal role of members on a corporate foundation board is to assist the top executives in decision-making as advisors or experts, similar to the roles described above. In many regions, such as Latin America, corporate foundations may be tantamount to family foundations because the company is family held.

Advisor role confusion can result in several ways. First, the principal decision-maker may not clarify roles at the beginning. Some people who are brought on a foundation board may assume that they are advisors, whose opinions become input for the primary decision-maker, but others 
may assume that their power, voice and vote are equal to others. Legally each board member has equal responsibility, but that does not mean that the principal intends for the decision-making to operate that way. Role confusion can also result when circumstances change, and board roles do not keep up with the evolution of the decision-makers' interests. Finally, confusion will result when behaviors are not consistent with stated intentions, as in the case of the Jacobs Family foundation mentioned above.

Where there is money, there is always the possibility of power plays. Some board members may in fact have more influence over the principal than others. In some cases, rivalries and jealousies may result over the perceptions of unequal influence. In a few cases, there may be explicit moves to change the power balance such as voting certain people off the board or adding allies who can outvote certain members.

The role of advisors, like informed givers, can also lead to imbalance. While advisors probably have satisfying influence, the danger is they may fall short in their institutional responsibilities. Early clarity about this is important, particularly where close friends or colleagues are involved. A range of choices about these arrangements is possible. Keeping advisors just that, and not making them board members, is one option, so that their advisory role and decision-making responsibility are not confused. It is also possible to establish procedures that separate deliberation about grants from actual approvals, such as giving an executive committee exclusive rights to grant approvals.

Summary. Achieving a balance between informed giving and institutional trusteeship begins with acknowledging the legitimacy of both roles. The key to thwarting the negative behaviors we often attribute to board members who are too attached to giving may be to pay more attention to the roles that allow for the many more ways in which trustees can have influence in the work.

\section{The Institutional Trustee Role}

Once boards hire staff, the challenge is to define the roles of the board and to divide the decisionmaking between the board and staff to allow sufficient influence for the board and clarity for the staff. There is a fairly standard model of division of responsibilities in corporate and nonprofit 
boards. The boards "govern" or set policy and remain at the mission and strategy end of the spectrum. Their responsibilities may or may not include evaluation. The tasks of these boards are therefore often described as "pre- and post-operations."

Foundation boards do not adhere to this standard model. As mentioned earlier, foundation boards have flexibility in assigning themselves decision-making responsibility in all six of the arenas (mission, strategy, structure, grantmaking, relationships, evaluation). Just because there is a staff, trustees do not necessarily give up their informed giver role. As the foundation world has become increasingly professionalized, foundation boards and staff have become more sophisticated in their decision-making, and manage to avoid the problems associated with total lack of clarity about the division of responsibilities. However, ma ny have not yet learned to avoid the pitfalls associated with the three common ways in which roles are divided: coproducers, grants approvers and policy-makers.

\section{The Co-Producer Role}

Boards of staffed foundations can actually share the work with the staff. A New England family, active in the ownership and management of a privately held company, operated their foundation in its early years without staff. They asked close associates to help identify individuals with significant relevant expertise in the family's philanthropic interests to join them on the board. The board then did all the work with part-time assistance for several years. When they eventually recruited full-time professional staff, instead of relinquishing all work other than policy setting, they shared the work with the staff. Board members participate in analysis, planning, engaging with grantees and monitoring of grant strategies. Here is the key: since this arrangement was the expectation from the beginning, it has become a comfortable and productive use of staff and board alike. This "co-investor" structure is facilitated by the foundation concentrating in a few large areas for their grantmaking.

Trainees. Sometimes inexperienced trustees may be chosen for the board in a trainee role in order to prepare them for future service. Family foundations will frequently use a few trustee positions to train younger family members in philanthropy. One might see emerging executives 
placed in rotation on corporate foundation boards to acquaint these people with the culture and strategies of the corporation's community involvement. These trustees-in-training may end up with duties that involve them more in the work of the foundation as a learning experience.

Experts. It is normal and advantageous to invite program area experts to serve on a foundation board. They may be frequently engaged with staff outside of regular board duties in the design, execution or evaluation of programs. It is not hard to imagine the pitfalls of board members who may be expert enough, or even more expert than staff, to make decisions on their own. Confusion, and perhaps contention, arises when it is not clear whether the expert is there to advise the board with enough information to help the group make a decision, to advise, or even oversee staff, or whether she is there to be the primary decision-maker. The original purpose might have been the advisor role, but groups can quickly fall into patterns of behavior, frequently just out of deference, where members give the final decision over to the expert. This may be one of the few examples of too much influence in too small a sphere. Adele Simmons, the former CEO of the MacArthur Foundation, provides this observation after working for years with the selection process for the MacArthur "genius" awards: "In areas where there is room for a great deal of subjectivity, such as poetry and music, the personal preferences of experts on the committee would have an influence, and candidates would have difficulty, or success, in part because of these preferences. This is, to some extent, inevitable, but it balances out over the long run, as people on the selection committee have limited terms. One just has to recognize this and watch for it."

Ms. Simmons also had observations on the evolution of expert roles: "When (the foundation) was developing its programs, we had trustees who were real visionaries - they designed programs in the environment, peace and international security and human development - using lots of outsiders, regular seminars at the foundation, and usually one key staff person.... We had to deal with conflict of interest issues because some of the best work was being done at places these board members were associated with. Early on this was fairly informal, it became formal later. Then the rest of the staff was hired as the programs took shape. When the specialists died, we had more of a generalist board. This can have a drawback, too, because these people are not 
as connected to the cutting edge of the field. In an ideal world, a good board includes people with expertise in the areas of interest to the foundation as well as generalists."

It is very difficult to maintain a distinction of roles when board members are authorized to participate in the work of the foundation alongside the staff. Lack of clarity can result in three issues for the foundation. First, it may be difficult to create a good working relationship and also avoid redundancy in what the board and staff do. The board will rarely have the time and flexibility to add distinctive value always when it is needed, thus putting an extra burden on staff. Second, the board members may lose their ability to be objective stewards of resources and activities the more they are part of creating those activities. Third, while they may be in a position to evaluate staff more closely, they may lose their ability to be objective about the staff and programs. Thus, close attention must be paid to maintaining the proper oversight responsibilities.

\section{The Grants Approver Role}

Many foundations maintain a rule, or tradition, of the board approving all grants. Despite the problems cited above associated with boards doing this, it is quite normal and customary for boards to retain this responsibility. It can be done well, which would mean that the activity is done with sufficient knowledge and accountability to make it a "real" function and that it does not create excessive cost over value for the staff. 
The problems that can be associated with boards that approve grants are in role confusion or cost. For example, the board of a large, staffed family foundation approves grants rather than set policy because policy discussions bring out the deepest ideological divisions among its many multi-generational members. However, the board is not satisfied just to trust staff to present a docket for their approval. The board has developed many committees representing the program areas, and the staff is responsible for educating these committees about their program and grant making strategies. The challenge is to contain the redundancy and cost that might be associated with these processes that otherwise are highly valuable in creating opportunity for influence.

The Merian Foundation in Basel, Switzerland, led by Christian Felber, is an example where grant making by the board seems to work well. This is an old and well-respected foundation. With a staff of 70, it has a grant making division and several operating divisions in printing, art, agriculture and real estate. There are seven trustees elected by the "bourgeoisie" of the community (the people elect a parliament that elects the board). Felber estimates that the board spends about two-thirds time on philanthropy and one-third on real estate and other operating matters. The board meets once per month for four hours and reviews every grant recommendation. Christian says, "They love grant making. I have very little discretionary money." The board is engaged in other ways. Each year the board goes on a two-day visit to another community to learn about programs. Every other month the staff arranges a site visit to a grantee for the board. Christian believes that the structure works well for what it is designed to do and that the board president and other trustees are satisfied as well. He describes the value of the decision-making structure as follows: "They control me. They make me feel responsible. I'm not tempted to push my own agenda." This board seems to reflect a good balance among creating accountability for performance by staff, meaningful engagement and public accountability.

\section{The Policy-maker Role}

Many staffed foundations define the board's responsibility at the mission and strategy end of the spectrum and turn to the corporate model for their governance design. The board is to establish or interpret the mission, approve strategies and assure that the grantmaking programs are 
consistent with the mission and strategy. Evaluation duties may or may not be included in their responsibilities. Much of the existing literature advises processes based on this model. But in many cases, the board does not really set strategy. It relies on the studies, options and recommendations from staff and consultants. It is clear that they approve strategy. But how else does the board really add value? Policy-making is important in theory, but potentially limited in practice. Herein lay the opportunities for problems with boards that are in the policy-making role.

While grantmaking foundations are the dominant form in the United States, operating foundations are the dominant form in Europe and Latin America. Many foundations do both. Foundations that are primarily operating, such as the Bertelsmann Foundation and many other foundations in Europe, have boards that are charged with overseeing the management of operating entities. It is misleading to think that operating foundations are easier to govern because they resemble corporations and therefore the corporate model of governance can be applied. While there seems to be a clear division of responsibilities in a corporation between governance and management, there is neither clarity nor precedent for such a division in operating foundations. Operating foundations are just as likely to have operating trustees as governing trustees overseeing a strong and independent management team. Operating foundation boards have to struggle with many of the potential problems that grantmaking foundation boards do, and then some.

What are appropriate divisions of responsibility that offer sufficient influence, yet avoid the problems cited for informed givers? A recent project on governance sheds some light on this question. Its authors describe two types of board roles at the policy end of the spectrum that add value. ${ }^{14}$ The first is a board that behaves a little like a bumblebee buzzing around the CEO encouraging vigilance, lest the CEO get stung by stepping out of line, similar to the way Christian Felber described his situation above. A foundation trustee explained a similar phenomenon by describing questioning by the board as useful when it came in the form of "ordinary questions about the work that required staff to think about their work in a non-jargon way." The second role described by Chait, et al. is more passive, but equally valuable. The

\footnotetext{
${ }^{14}$ Chait, et al. op cit. p. 3
} 
board creates what the authors call "sense-making opportunities" for the staff. Simply by meeting and maintaining consistent and predictable processes for what may seem like routine approvals, the staff has a chance to regularly take stock of what is happening, apply some critical thinking and prepare rationale for what they are doing or what should be changed.

Paul Brest, president of the Hewlett Foundation in California describes such a satisfactory arrangement with his board. Despite having very large assets, Hewlett has a relatively small staff because their grantmaking strategy emphasizes longer term relationships, large multi-year general support grants that result in fewer grant transactions for the program staff. Brest reports, "The Board does approve individual grants. Grants used to take up virtually the entire Board meeting. During the past several years, the Board has become engaged in broader issues of strategy, reviewing strategic plans proposed for each program by the program directors and president, and reviewing proposals to close some existing programs and develop new ones. Most of the programs have Board task forces that assist the program directors in developing and reviewing strategies. Increasingly, I think the most important role the Board plays for me in my capacity as president - as distinguished from their important trusteeship and auditing responsibilities - is that it provides different and sometimes unexpected perspectives on issues that the staff and I have thought through." He described his board as focused on their fiduciary responsibilities and stewardship of the donor's intent, trusting him to implement strategies competently. He has found substantial value in being able to call on them individually. In this way, they end up being involved or knowledgeable in different pieces of the work. The role of the board is well understood and aligned with the processes and strategies of the foundations. Board members' level of influence is consistent with their expectations.

Chait, et al, propose that boards that are in the policy-making arena focus on becoming more competent in three modes of work. They propose moving from fiduciary oversight to inquiry, from strategic planning to strategic thinking and to become engaged in "generative" work where boards provide a source for leadership.

What are the common problems associated with policy-maker roles?

1. Strategy as straightjacket. A foundation board that is restricted to the policy end of the spectrum may indeed embrace this role and attempt to do it well. Lucy Hays Nesbeda, 
granddaughter of Edna McConnell Clark and a trustee for years of the foundation of the same name, described a high quality process used there. The foundation had excellent staff with knowledge and experience in their fields. Experts were brought in from academia and practice to advise the staff and board during planning processes. Board members were part of subgroups learning about the program areas in detail. Five to seven year plans were established and staff was held accountable for the goals and regular reporting against these plans. Nesbeda had an interesting observation however. She noticed that while in some areas, such as disease research, the long-term plans served the program purposes well, in others, such as criminal justice, they did not. In a social policy area the political and economic environment, at the federal, state, or local level, could change drastically within a few years time, and make the original assumptions underlying the program irrelevant or unrealistic. At other times, events might create opportunities that would require major changes in spending plans that became difficult once the staff and board were locked into their plans. The need for detailed and complex justification from staff, and the usual focus on implementation serve to create a situation where both staff and board can go on "autopilot" once policy is set. This situation can create excessive ownership among staff of their plans and programs, resulting in predictable resistance to change.

2. High cost for questionable value. Foundation CEOs described one set of problems with boards in the policy role as value for investment. The board demands a huge amount of time, but doesn't seem to create equivalent value, representing alignment failure. The following comments reflect this theme: "To some extent I think I'm running a production operation instead of one that's creative, reflective, and insightful about what we ought to be doing. In the preparation for the board a lot of good work actually gets done... I just want all the brain damage to stop. I know the board doesn't read all that information;" and, "A frustration that I have in general is the inefficiency in the way we do our work in foundations and how much time we spend on the form over the substance, in the paperwork. Most of our time is spent on donors and boards, making those decisions happen. I would like to spend more time on the mission, actually working with organizations and finding out better ways we can actually work with them." 
3. Disengagement/Lack of interest. Disengagement can result when the board plays only a policy-making role with too little meaningful work. This disengagement can threaten the ability of a board to be responsible in its duties. One CEO described his fears about this, "That's another thing that keeps me awake at night: 'My God, the board doesn't have any idea what we are doing.' When they were signing off on grants, they may not have understood everything we were doing, but they at least knew where the money was going. Now, obviously, they re getting an awful lot of reporting from us, but given busy people and all the rest, I'm not entirely sure that they are really engaged with what we are giving them"

A former program officer of a foundation described another form of disengagement. The board met once a quarter for one hour plus lunch. The docket was normally 60 grants. The staff arranged the docket so that the least controversial grants came first, occupied a lot of the time, with the more contentious grants at the end. The latter grants were normally voted through as a block due to lack of time, as the board members heard the tinkling of glassware being put in place for lunch. This board essentially operated as a pleasant social obligation. This may provide value to the participants and may confer legitimacy and credibility to the foundation by the prestige of the individuals, but it does not provide value to the foundation either in accountability or effectiveness.

Another set of family board members discovered that hiring competent staff to help them develop strategy and recommend grants ended up removing them too much from the interesting part of philanthropy. ${ }^{15}$ The third generation group of the New York-based Kaplan Foundation decided that they would make grants as a group rather than divide up the money for each of them to grant individually. They hired a well-respected CEO who proceeded to develop an excellent grantmaking strategy consistent with the mission that the cousins had developed. After several rounds of grantmaking in this vein, the cousins began to lose interest. The passion and fun of the work was missing for them, so they ended up reverting back to doing the grantmaking process on their own. It is important to

\footnotetext{
${ }^{15}$ Husock, Howard, The Kaplan Family Foundation, KSG Case \#1551.0
} 
note that neither one of these structures is right or wrong, or good or bad. For this group, staff did not let them have the personal involvement and influence that they wanted.

4. Meddling. Board members who are confined to the policy role may end up with very little to do. If in reality a competent staff actually prepares the policies, there is little of real value for the board members to chew on. Starved for influence, the board "acts out" by meddling in unproductive ways in decision-making areas reserved for staff. The classic case is the board members who takes calls and requests from his own contacts and tries to push through grants for his favored organizations. Staff end up frustrated by their thwarted influence in having to administer a grant that they may not agree with. Our research has revealed that organizations that receive their grants this way may end up being less responsive to the foundation processes because they have an "inside track." 16

Another form of meddling is that despite a formal agreement to let staff handle grantmaking, board members still spend excessive time going over grants. The CEO of a very large family foundation in the U.S. expressed his frustration: "I think our trustees are having a hard time weaning themselves away from grants. I'll tell you, the bottom line is they love the grants. They like looking at them. This is where the rubber meets the road. Not only that, we look at all the grants we deny to make sure there isn't something there that we might like." The issue here is not one of bad policy about decision-making. It is a matter of inconsistency with expectations for the division of decision-making.

5. Inquisitorial behavior. A program officer and trustee of a large private foundation described an era in which the board essentially operated as inquisitors (similar to a legislative hearing) of the staff each quarter. The role had evolved into one of, "Let's see if we can catch the staff in mistakes." The trustee described this behavior as one way that accountability might be demonstrated, and it served to help trustees feel as if they had influence, albeit in a twisted way. But both persons acknowledged that this created counter-productive, conservative behavior in the staff.

${ }^{16}$ Letts, Christine, Ryan, William, “Alignment as Strategy,” forthcoming, 2004. 
Experts can create confusion in the way they deploy their expertise. Adele Simmons said, "Board members that are politically astute - understand process, what boards do and how they do it - are a big help. A board member can nitpick any project, particularly those in fields they know....One might nitpick a project that he actually supported in a board meeting, and inadvertently undermine it entirely, not understanding that those are conversations one had off-line."

6. Amateurism. People may end up on a policy-making board of a foundation without regard to their skills or expertise. The head of a well-respected think tank described his experience joining a family foundation board. After a few meetings, he realized that he had inadvertently taken up the role as inquisitor. He had a lot of knowledge of the policy areas in which the staff was doing grantmaking and could engage them with very challenging questions. Because of lack of knowledge and experience, this was work that the other board members were not equipped to do, so our think tank leader ended up setting up the staff negatively in front of the other board members. He realized that he could be more constructive to the staff by vetting policy proposals before they got to the board. He was surprised to find that his assumption of the conventional model of "board makes policy, staff implements" just did not apply in this situation. The family members who were on the board did not fit the real work required of a policy-making board. The staff had the expertise to design and implement the strategies and the board was satisfied spending their time approving the resulting grant recommendations.

The problems of amateurism may affect operating foundations more than grantmaking ones. First, trustees are rarely chosen from the same ranks as staff. Unlike a corporation where the top leaders are people who have extensive experience or skills relevant to the division they run, trustees who end up as the chief manager of a foundation division may have no previous experience in that arena. They may come to the trustee job as close and trusted associates of the founder or board chair. They may be valuable in creating a cohesive decision-making unit or in providing legitimacy, but they may be amateurs substantively. One high-level staff member of a European operating foundation described the expertise of several board members as that of "well-informed newspaper 
readers." These board members need to be dedicated to learning and catching up to staff and resist the temptation to start new initiatives just to put their own mark on the work. The latter problem can be particularly seductive in the absence of clear evaluation that helps the organization set priorities based on data.

7. Problems of lifetime roles. Tenure is another problem that may particularly affect operating foundations. Automatic rotation or term limits may exacerbate the learning curve problem above. Just when a trustee becomes knowledgeable enough to play his role effectively, he may be rotated off. However, longer tenure creates its own set of problems. The ability of a single individual to control the agenda for a part of the foundation can become extreme in an operating foundation where a trustee with long tenure manages the same division. To the extent that other trustees abdicate responsibility for the "whole" in deference to each managing trustee the absence of external accountability coupled with long tenure creates the conditions for abuse.

\section{Informed givers and institutional trustees have different risk profiles.}

Foundation executives and board members are used to talking about taking risks on programs that may not have a clear chance of achieving their goals or on organizations that may not reach sustainability. ${ }^{17}$ If risk means consequences for the decision-maker, claims of risk such as these are usually misplaced. The risk, and consequences of success and failure, is usually held by the grantee, not the foundation. Indeed, program officers may even be rewarded for so-called risks that fail rather than suffer consequences, as board members are fond of saying, "If we don't incur some mistakes and problems, we probably are not doing our job." Then what kind of risk do foundations really have?

There seems to be two other ways in which risk affects the behavior of foundation boards and staff. First, there is the risk of embarrassment, either in the eyes of the public or peers. This could occur by the foundation making bold claims that are never realized or by taking positions on policy issues that fail. We actually see far more individuals, such as Ted Turner with his $\$ 1$ billion gift to the United Nations, take public risks such as these rather than institutions. One foundation leader said, "Individuals take risks, not institutions." If we find foundations too timid or conservative, it may be due to people in leadership positions who are averse to this kind of exposure. It may be that the trustee in his role as informed giver (as in the case of the MacArthur Foundation expert) may be more willing to engage more risk than as the institutional trustee.

The second kind of risk is opportunity cost. If a foundation board makes a "big bet" in which they decide to put a large, disproportionate, amount of resources toward one idea, project, or institution, they will forego the opportunity to invest in other things. The larger the bet, the higher and more visible the stakes are for the results. If the results are bad or inconclusive, the board can be criticized for that opportunity cost, or at least for not appropriately hedging their bets. Stock portfolios that are "balanced" with a variety of stocks are considered less risky. It would not be surprising if this principle were not implicitly used in foundations, because most grantmaking foundations give out many grants in multiple subject areas.

${ }^{17}$ Risk was the subject of an unpublished paper used by the Executive Session on Philanthropy, Hauser Center, 2001. 
The foundation board sets the tone for whether risk is appropriate and will ever be considered. Without explicit consideration, it is not likely that the sum of trustees' individual inclinations toward risk will result in coherent strategy. Boards need to understand and deliberate the apparent "risk profile" of their portfolios to be clear whether their intentions are being actualized.

\section{Responsibility for Impact - The Accountability Role}

The board should determine to whom the foundation is accountable, and for what.

Adele Simmons acknowledges the costs and benefits of the flexibility and relative lack of accountability in the following statement: "The lack of accountability is two-edged. Because of it, foundations can take huge risks. There is no shareholder looking at the bottom line at the end of the quarter. Lack of accountability can provide great freedom for risk, new ideas, experimentation, but it can also be abused. I am not sure how one balances these two, except with basic laws such as we have about self-dealing and transparency." All foundation board members are institutional trustees regardless of additional activities they engage in or roles they play. In addition to establishing what the foundation is to $\underline{\text { do, }}$, the board should establish how the foundation should be held accountable. This includes their decision about how they intend to communicate with constituents and how they intend to evaluate the foundation's work. There are a lot of guidelines about appropriate and respectful communication procedures. Remaining private will become increasingly difficult. Evaluation may be considered across the other five arenas of decisions, from mission to grantee relations. The board should familiarize itself with the growing literature on foundation evaluation and decide what kind and how much to do. Boards are more likely to be held irresponsible for the failure to consider accountability and evaluation rather than choosing the wrong type. As discussed earlier, accountability is not synonymous with transparency or publicity. A board can install excellent, but private, processes to hold themselves accountable and to measure results. Indeed, no amo unt of public scrutiny will substitute for integrity among a foundation's leadership.

Operating foundations face particular challenges in accountability. Operating foundation trustees could adopt the image of feudal lords who have the ability to dispense resources without regard to impact or performance. If the board divides responsibility for operating divisions among the members, many of the hazards discussed thus far are present, such as lack of accountability or 
evaluation due to deference. Operating foundation boards that adopt the traditional corporate structure are essentially putting themselves in the policy-making role explained above, but are also responsible for overseeing managers who are expected to produce certain results directly, some of which are very difficult to evaluate.

There are some types of programs in operating foundations that are easy to evaluate. This is the case with real estate operations that can measure return, artistic companies or museums that are subject to critics, or farms that can measure their output. However, in social service areas, evaluation may even be more challenging than it is for grantmaking foundations. Many boards are dissatisfied with measuring activities or outputs, but determining outcomes is expensive and elusive. It is difficult to get objective and honest feedback from partners or communities that benefit from the foundation's activities. These phenomena make it difficult for governing boards to be sure that they are fulfilling their responsibility. This may be why many revert to managing roles in which they are able to exercise their influence more directly.

Further, formal outcome evaluations may be ill suited to the needs of an operating foundation that is inclined to revise its approach as conditions change. A staff manager explained: "We should be aware of the fact that carefully done evaluation may well be quite critical of board decisions and board suggestions. At least from the experience of our own foundation, this is a notion that can be a challenge to the entrepreneurial freedom of a board and of a chairman. When our chairman discovered that a systematic approach to evaluation could also put limits or judgments on his own discretion, this was a clear challenge to the decision-making authority of the board. It turned out that the board chose a rather entrepreneurial option, saying...we take entrepreneurial action and work for accountable and responsible management on an ongoing level."

Public foundations, such as community foundations, and foundations formed through some process of public rule, such as the health conversion foundations in the U.S. and the bank conversion institutions in Italy, usually have a unique set of governance role clarity and accountability challenges. Most community foundations have charters that allow different elected bodies or individuals to appoint trustees. They frequently have term limits. The 
combination of these two phenomena can cause up to $50 \%$ turnover in trustees in some institutions over just a few years. This turnover creates several problems. First, it increases the problem of amateurism. Trustees may end up on the board due to political connections, prestige in the community or as executives-in-training. None of these attributes equips the individuals for philanthropy or even community involvement, nor do they necessarily equip the individuals to relate to each other as a group. Second, it increases the institution's reliance on the staff. The staff maintains the continuity and the trustees must rely on the staff for most of the information. With this lesser opportunity for influence, and disparate community connections, the temptation to meddle is great.

Many foundations in Europe have a state representative by law. Such is the case with the Italian Bank foundations established in the mid-1990s. These individuals could be appropriate agents of accountability, but for what? Lack of clarity in public foundations revolves around mission and the role of trustees. How much freedom should the trustees have to craft the mission? How much should the community be able to contribute to this decision? Are the trustees representatives of their respective whole (like the U.S. Senate)? The charters of the foundation rarely answer these questions, which are frequently the subject of an "invisible deal," which can evolve and change over time. Disparate accountability and lack of mission clarity rarely result in harm. However, there may be enormous opportunity lost, as these groups of odd fellows agree on many small, nice grants, but may not be able to agree on initiatives that have the chance to change community conditions.

Even foundations that do not have official public charters can end up with public expectations that can overwhelm the foundation's flexibility and ability to be independent. The Gulbenkian Foundation of Lisbon, Portugal, by far the largest foundation in the country, attempted to transfer the orchestra that it operated to the state. There was public outcry, because the community believed that the state would not be able to maintain the quality that the company had developed under foundation management. Under this pressure, the trustees decided to keep the orchestra. Freiberg Stiftungverwaltung, a four hundred year old foundation in the southern part of Germany, faced a decision on whether to make up a large public revenue cut to local theaters that the town had to make. The fact that the mayor of the town is the chairman of the board certainly 
complicated this decision. It is possible that the Italian bank foundations will end up with pressure to support public programs because of the connection to the state.

Foundations in the United States end up with similar public expectations and pressures. With the increasing mobility of generations of family, communities claim to be "abandoned" by family foundations that may have been an important contributor to the town through the years, but whose board now contains children who do not live there and have strong interests elsewhere. The Ewing Marion Kauffman Foundation, in Kansas City, Missouri came under public scrutiny because of plans to phase out grants to community groups that had regular funding from the foundation. ${ }^{18}$ The resignation of three board members over this added fuel to the controversy.

Boards that listen to the advocates who encourage them to be accountable through communication and transparency will potentially face the public scrutiny and pressures similar to those faced in the examples above. It is no wonder that many boards choose the maximum anonymity that the law allows and that annual reports end up as public relations tools rather than detailed explanations of intentions and results.

It is easy to dodge the responsibility for impact question with assumptions about the quality of staff and process. The board should explicitly decide to whom they are accountable, and for what. They then need to decide how they will check on whether they are fulfilling their aspirations.

Once roles are set, the board should establish periodic reviews to assure that the set of policies and practices as implemented meet their intent and expectations.

Boards need to assure themselves that processes are accomplishing their intended purpose. Are the processes living up to individuals' (both staff and board) expectations? More important, are the policies and practices aligned with each other? The arenas in which foundations work are dynamic. Establishing a regular time and process to check in on this question sets the board up to be adaptive to the changing needs of the environment and staff and board individuals. Recent

\footnotetext{
${ }^{18}$ Anft, Michael, “Kauffman Board Members Resigns...," Chronicle of Philanthropy, September 18, 2003, p. 11.
} 
studies of grantmaking strategies and nonprofit board practices support the idea of emergent strategy, regularly informed by staff (or board members) that is in the field, closest to the action. $^{19}$

As foundations grow and evolve, the board responsibilities will change. Family foundations "grow up" into independent institutions. A living donor will decide to dramatically change his involvement. A long-time CEO will finally leave. A community crisis forces a foundation to change its strategy abruptly. Tension will inevitably result if the organization does not recognize inevitable evolution and the board processes and structure do not adapt to the changing needs of the community, organization and staff.

\section{Summary}

The foundation field is appropriately beginning to focus on the behavior and processes of foundation boards. There is a growing body of literature that offers advice on structures and procedures to ensure that boards are meeting their stewardship responsibilities. However, achieving foundation board effectiveness is complex and entails more than this literature suggests. The nature of philanthropy - generosity - and the flexibility that is a feature of foundation structure demand that we consider as legitimate many more roles than are typically considered in the literature. By focusing on roles, we will improve the work of foundation boards and their results.

\footnotetext{
${ }^{19}$ Letts, et al. op cit., p. 22
} 


\section{APPENDIX 1}

\section{ACHIEVING CLARITY, INFLUENCE AND IMPACT: GUIDING QUESTIONS FOR FOUNDATION BOARDS}

These questions are intended to help a foundation board achieve clarity of roles, appropriate influence in decision-making and improve the foundation's potential for impact. The questions do not necessarily have right or wrong answers, but are helpful as a basis for discussion.

I. General (These items might be documented in a board orientation book.)

- What are the legal requirements of the foundation?

- What are the legal responsibilities of the board members?

- What are the requirements of the trust or by-laws?

- What processes are in place to help the board fulfill the legal and trust requirements? How much time is required, of whom?

- What staff or resources are available to assist the board?

- What is the compensation for board members (time and expenses)? Does this meet legal or industry guidelines?

- What are the standard processes (meetings, reports, procedures) in which board members are expected to participate? Where?

- What is the estimated total time commitment per year for a board member?

- What are the terms limits and nomination processes for board members?

\section{Clarity on Roles}

\section{A. Boards with Staff}

- What is the board's group role in the following decision-making areas?

Mission development and review

Strategy for Impact; Overall budget

Organizational structure and culture

Grantmaking strategy; grant processes

Grantee Relations

Evaluation 
Examples of roles:

Creation

Approval - voting required

Advisory - notification/review/comment

Information only

None

- What role do individuals on the board have, if different than the group role? Why?

- What processes (committees, meetings, reports, procedures) are in place to allow the members to fulfill their responsibilities?

- What staff support or resources are available to assist the board members?

- What is the respective staff role (who, what, when) in each of the above decisionmaking areas?

\section{B. Boards as Staff}

- What role does the board as a group have in the above decision-making areas?

- What is the division of responsibility among the board members for the work associated with the decision-making areas above?

- What processes are there to help the board members fulfill their responsibilities (meetings, reports, procedures)?

- What administrative support or resources are available to help board members?

- What is the expected time commitment for each board member?

III. Influence (Questions for individual board members)

\section{A. Expertise/Relationships}

- Why were you asked to join the foundation board?

- Is there a particular knowledge base/skill/relationship base that you think is relevant to the work? That you have been asked to use?

- Do you feel equipped for the role and decisions that are expected of you?

\section{B. Preferences}


- What do you enjoy most about your foundation work? Why?

- What work or activities do you consider most important? Why?

- What work would you suggest dropping from your responsibilities? Why?

- What work do you think you should do more of? Why?

\section{Time/Resources}

Estimate the amount of time you spend in the various roles and activities as a board member....

- Is this about right? Too little? Too much? Why?

- Are the resources adequate to help you be effective? If not, what do you need?

IV. Accountability for Impact (These are programmatic rather than legal in nature.)

- Who are the stakeholders of the foundation?

Living donors
Family
Community
Grantees
Employees
Politicians
Media
Public at large
Other?

- What accountability does the foundation have to each of these?

- How does/will the foundation fulfill this accountability?

- What collective or individual responsibility does the board have to achieve this accountability?

- What processes have been established to fulfill the accountability goals or requirements?

- What time commitment is expected of board members for these activities? 


\title{
APPENDIX 2
}

\section{A Review of Foundation Board Training Literature}

\author{
2004 Melissa Wickman
}

When a man assumes a public trust, he should consider himself a public property.

$\sim$ Thomas Jefferson

This above quote from Thomas Jefferson serves as a reminder for those who assume roles of public service. Society expects such individuals to act responsibly and make decisions for the greater good. Yet one may also interpret the quote as a warning. Those who take on the public's trust are often held to a higher standard and can experience tremendous scrutiny during their tenures. Elected officials, teachers, peace officers, even board members of nonprofit organizations are potential targets for public inquiry. Therefore, it should come as no surprise that board members of foundations also endure such examinations. For example, the Boston Globe recently ran a series of articles that focused on questionable behavior exhibited by some board members of local foundations. ${ }^{20}$ The articles typically highlight excessive perks and questionable grantmaking practices.

There are serious ramifications each time a board member abuses the power granted through their position. Not only are there fewer dollars available for worthy charitable organizations, but the general public loses faith in the philanthropic community. Foundations are no longer considered immune to the scandals that are typically attributed to the private sector. Yet popular media and law enforcement continue to focus on stricter federal regulations as a means of prevention. It is rare to see a call for increased education and training for foundation board members. Even if foundation leaders heeded such advice, it is unclear where they should turn for literature and training materials.

Although some may believe that directors should know better, there are no legal requirements that directors must receive training in order to serve. A few organizations provide training for foundation board members, most notably Board Source and the Council on

\footnotetext{
${ }^{20}$ Healy, Beth et al, Boston Globe, 2003
} 
Foundations. ${ }^{21}$ The Council on Foundations publishes Foundation News \& Commentary, which occasionally prints columns and articles that address specific foundation board issues. Finally, the Foundation Center web site has a topical resource list that offers annotated bibliographies of books on nonprofit boards. ${ }^{22}$

I recently embarked on what I thought would be a simple assignment - creating an annotated bibliography of written materials focusing on foundation board development. I discovered plenty of materials that addressed issues concerning boards of directors for charitable organizations. There are also books for boards of large foundations that manage universities and hospitals. Even books and articles written for family foundations include sections addressing their boards. However, my search for writings that specifically address the unique responsibilities required of grantmaking boards generated few results. Many of the publications are more than ten years old. Most of the books and articles emphasize structural recommendations for foundation boards. Such questions are most helpful for newer foundations. For example: What is the size of an ideal board? How should boards run meetings? How long should someone serve on a board?

However, models for good foundation governance do exist. One such example is a slim tome titled Trustees and the Future of Foundations. Written by John W. Nason and published in 1977, the book provides one of the few comprehensive looks at the roles and responsibilities of foundation trustees. ${ }^{23}$ Although the statistics in his first book are outdated (he refers to 26,000 foundations with combined total assets of approximately $\$ 31.5$ billion) his recommendations remain valid today. ${ }^{24}$

Nason does an excellent job of summarizing his main points in the final chapter where he lists the following nine responsibilities of foundation trustees: 1) recognize that they serve a public trust, 2) plan a program or programs of philanthropy, 3) make hard choices among public needs, 4) diversify board membership and broaden outlook, 5) plan for continuity and renewal of board, 6) organize for effective operation, 7) make the foundation accessible, 8) be familiar with

\footnotetext{
${ }^{21}$ Board Source is a nonprofit organization that offers a variety consulting and training services for nonprofit boards. Board Source also has a large collection of written materials for purchase.

${ }^{22}$ Foundation Center. http://www.fdncenter.com

${ }^{23}$ John Nason was the former president of Swarthmore and Carleton Colleges and served as a trustee for the Council on Foundations.

${ }^{24}$ The most recent survey (2001) conducted by the Foundation Center identified more than 61,000 foundations with assets totaling almost $\$ 477$ billion. <http://fdncenter.org/fc_stats/pdf/02_found_growth/04_01.pdf> February 8, 2004.
} 
and to fulfill all legal requirements, and 9) give public accounting of activities. ${ }^{25}$ Nason revisits his recommendations in a subsequent analysis printed in 1989. This version, titled Foundation trusteeship: service in the public interest, is still available in print.

Yet much has changed since Nason's last publication, such as the passage of the Sarbanes-Oxley Act and renewed interest in foundation accountability and transparency. The philanthropic field requires a fresh and comprehensive look at the role of board members in foundations. Until then, foundation leaders will be required to navigate through the fragmented body of literature that covers foundation boards.

The following annotated bibliography is meant to serve as a guide for those who wish to strengthen their organizations by having informed board members. The list brings together articles, books and tools available for use by foundation boards. While some are readily available from publishers, others may be out of print and can be obtained through some university collections or via the Foundation Center Library in New York City.

\footnotetext{
${ }^{25}$ Nason, John W.; Goheen, Robert F.; Council on Foundations. Trustees and the future of foundations. Washington, DC: Council on Foundations. 1977.
} 


\section{ANNOTATED BIBLIOGRAPHY}

Abstracts provided by The Foundation Center ${ }^{26}$ except where noted. All of these resources can by found at The Foundation Center library in New York and have limited availability at other Foundation Center resource centers. Books are also available directly from the publishers (e.g. Council on Foundations) and some national retail book stores.

\section{General Resources}

Carson, Emmett D. "Worst-case scenario or the perfect storm?". Foundation News \& Commentary vol. 45 (January-February 2004) p. 18-22.

The author catalogs various recent challenges to foundation boards and recommends strategies for dealing with them.

Cuninggim, Merrimon; Council on Foundations. Letters to a foundation trustee : what we need to know about foundations and their management. Washington, DC: Council on Foundations. 1991. vi, 28 p.

Paper written in the format of a series of letters to a friend who is about to join a foundation board. Discusses the roles and responsibilities of foundation trustees, including grantmaking, relationships with other foundations, personnel policies, and accountability.

Foundation Governance: The CEO Viewpoint. The Center for Effective Philanthropy. 2003

Houle, Cyril O. The effective board. 1960. Reprint. New York, NY: Association Press. [1980]. 174 p.

Nason, John W.; Goheen, Robert F.; Council on Foundations. Trustees and the future of foundations. Washington, DC: Council on Foundations. 1977. 112 p.

Analysis of the role of foundation trustees in today's society, covering such topics as public accountability, professional staffs, and the 1969 Tax Reform Act. He concludes that foundations are in danger of being torn apart between two opposing views of what is best for American society, and that foundation trustees are crucial to preventing their institutions from being destroyed. Includes brief bibliography.

Nason, John W.; Foundation Center. Foundation trusteeship : service in the public interest. New York, NY: Foundation Center. 1989. xi, 173 p.

Nason provides a major reassessment of the responsibilities of foundation trustees. Examines the present state of the foundation universe, the importance of foundations to American society, why foundation performance is falling short of its full potential, and how today's trustees can face the challenges before them to help improve foundation performance. Discusses the modern foundation's dual nature (as privately organized public institutions), the complexities involved in developing programs for a changing society, the three routes to board membership, qualities of a good trustee, the dynamics of an effective board, the advantages and disadvantages of staffing, the respective roles and obligations of board and staff in foundation management, and the

\footnotetext{
${ }^{26}$ Copyright $\odot$ 2004, The Foundation Center. All rights reserved. <http://lnps.fdncenter.org/dbtw-
} wpd/exec/dbtwpub.dll.> July 25, 2004. 
question of compensation. The study also investigates the issue of full disclosure, and examines the effect of the new tax laws upon foundations. Bibliography.

Prager, Denis J. Organizing Foundations for Maximum Impact: A Guide to Effective Philanthropy. Colorado. The Aspen Institute, 2003.

Wood, Miriam M.; Leaman, E. Lewis. Governing board oversight of donor dollars : the Foundation for New Era Philanthropy. New Haven, CT: Institution for Social and Policy Studies. 1996. 17 p.

Young, Donald R.; Moore, Wilbert E. Trusteeship and the management of foundations. New York, NY: Russell Sage Foundation. 1969. viii, 158 p.

Zurcher, Arnold. Management of American foundations : administration, policies, and social role. New York, NY: New York University Press. 1972. vii, 184 p.

Zwingle, J.L. Effective trusteeship : guidelines for board members. Washington, DC: Association of Governing Boards of Universities and Colleges. 1975. 39 p.

\section{Board Compensation}

Allen, Kent. "Conflicted over compensation". Foundation News \& Commentary vol. 42 (January-February 2001) p. 25-7.

More than three-quarters of the foundations that responded to a Council on Foundations survey on trustee compensation indicated that they do not offer payment of any kind. Yet there are notable exceptions, and the topic is controversial. The W. K. Kellogg Foundation, the Duke Endowment, and the John S. and James L. Knight Foundation are some that do pay trustees. Several notable leaders of the field offer their opinions about the pros and cons.

Draper, Lee. "A dubious legacy". Foundation News \& Commentary vol. 42 (March-April 2001) p. 22-5.

Should foundations pay their board members? This author presents his arguments against the practice, responding to an article by Kent Allen in the January-February 2001 issue of the same magazine.

Williamson, Richard. "Charitable funds going to least in need--foundation board members". NonProfit Times Financial Management Edition vol. 17 (15 December 2003) p. 1, 12-3. Describes examples of foundations that may be paying their board members excessively. Cites data from "Foundation Trustee Fees: Use and Abuse," published by The Center for Public and Nonprofit Leadership, Georgetown Public Policy Institute. Sidebar includes brief article "What is a 'reasonable' fee for a foundation trustee?"

Conflicts of Interest \& Controversy 
Anft, Michael. "State clears Kauffman Fund of wrongdoing". Chronicle of Philanthropy vol. 16 (18 March 2004) p. 34.

Attorney General Jeremiah W. Nixon of Missouri has cleared the Ewing Marion Kauffman Foundation of any illegal activities and conflicts of interest. Kansas City nonprofits had previously argued that the foundation under chief executive Carl J. Shramm was withdrawing support for Kansas City causes, questioning his interpretation of instructions left by founder Ewing Marion Kauffman. Former trustees had also accused the foundation of offering a job to an outgoing trustee, Brian O' Connell, shortly before voting whether to retain Shramm as chief executive. The Attorney General has suggest that the foundation review and clarify its policies to avoid similar conflicts in the future.

Bailey, Anne Lowrey; Goss, Kristin A. "Confidential review of Marin Foundation said to call for sweeping changes". Chronicle of Philanthropy vol. 3 (16 October 1990) p. 19. The "Marin Independent Journal" obtained and published a confidential review of the Marin Community Foundation's operation, which the trustees voted in June not to release. The review finds that unless the present structure of the board of trustees is changed, it "will prevent successful management of the foundation." It also criticizes the board for being too involved in the foundation's daily operations, rather than fulfilling its role as a policy-making body.

\section{Bailey, Anne Lowrey. "Turmoil at Gannett". Chronicle of Philanthropy vol. 2 (24 July} 1990) p. 1, 14-5.

Examines concerns that Gannett Foundation officials are spending too much money on expenses since Allen H. Neuharth retired as chairman of the Gannett Company in March of 1989 and began to devote more attention to his position as the foundation's chairman.

Casey, Constance. "A donor's messy legacy". Chronicle of Philanthropy vol. 12 (23 March 2000) p. 9-10, 12.

Discusses controversy regarding the disposal of multimillionaire Howard Gilman's estate since his death two years ago, and concerns regarding the executors of his estate being board members of the Howard Gilman Foundation.

Cohen, Rick. "Time to stop excusing the inexcusable : foundation trustees who play by their own rules". Nonprofit Quarterly vol. 10 (Winter 2003) p. 44-50.

Cohen, executive director of the National Committee for Responsive Philanthropy, decries the practice of fees, self-dealing, self-granting and other controversies on the part of foundation boards.

"One man uses a loophole to take control of foundation". Board Member vol. 9 (March 2000) p. 2-3.

Discusses the way in which William Wachenfeld used his position as a lifetime corporation member of the Hayden Foundation to dominate the organization and intimidate board members through his power to appoint or dismiss board members at will.

Rocque, Amanda. "Funds urged to appraise charity boards' quality". Chronicle of Philanthropy vol. 7 (29 November 1994) p. 30. 


\section{Donor Intent}

Bork, Robert H. "Interpreting the founder's vision". Philanthropy vol. 7 (Winter 1993) p. 1-3, 26.

Text of the keynote address of the Philanthropy Roundtable annual meeting, held October 29-30, 1993, in Colorado Springs. Judge Bork addressed the parallels between Constitutional interpretation and the interpretation of donors' intentions.

Brody, Deborah. "The past is prologue". Foundation News vol. 32 (November-December 1991) p. 39-41.

Advocates the use of oral histories to help preserve the vision of foundation funders and to help illuminate interrelationships between people and ideas within foundations. Discusses oral history as an academic discipline; provides advice on the planning and conducting of an oral history; and presents examples of foundations that have undertaken oral histories, with a focus on the Spencer Foundation.

\section{Foundation Specific - Community Foundations}

"Continuity in the family foundation". Family Business Review vol. 3 (Winter 1990) p. 40520.

Provides five authors' descriptions of innovative programs developed in various family foundations to deal with the challenges of recruiting, selecting and training new generations of board members.

The guide for community foundation board members. Washington, DC: BoardSource. 2003. 75 p.

Explains the structure and responsibilities of the board, with recommendations for effective practices. Appendix I reprints the National Standards for U. S. Community Foundations. Includes glossary and resource lists.

National Agenda for Community Foundations. National Training Project; Council on Foundations. Community foundation competency guide : self-assessment and action plan for professional development. Washington, DC: Council on Foundations. 1988. iv, 37 p. Basic workbook to help board members, chief executive officers and staff members of community foundations set personal and professional learning goals. Competencies are identified in the areas of mission and history, governance, resource development, management, grantmaking and community leadership, and communications and public relations. The workbook is complemented by the Council on Foundations' "Community Foundation Resource Guide", which identifies resources supporting the development of the above competencies.

National Agenda for Community Foundations. National Training Project; Council on Foundations. Governance. Washington, DC: Council on Foundations. 1990. viii, 50 p. 
Derived from the "Community Foundation Competency Guide", this manual examines legal and practical aspects involved in governing a community foundation. Details the legal parameters of the governing body; offers suggestions for educating the board about its responsibilities; discusses board composition, selection and structure; and examines the board's planning, administrative, fiduciary and ethical responsibilities.

National Agenda for Community Foundations. National Training Project; Council on Foundations. What's my role? A conversation with community foundation board members. [video recording]. Washington, DC: Council on Foundations. 1990.

Abstract: Organized into six topic as presented in the "Community Foundation Competency Guide", this film brings together five community foundation board members to express their views on topics dealing with mission and history, governance, management, resource development, grantmaking and community leadership, and communications and public relations.

Self-study guide for community foundation boards. Washington, DC: Council on Foundations. 1986. 16 p.

\section{Foundation Specific - Corporate}

Regelbrugge, Laurie. Making the most of corporate foundation boards : strategies and practices. Washington, DC: Council on Foundations. 2001. x, 104 p.

Published with the National Center for Nonprofit Boards (now BoardSource), this book provides various models showing the responsibilities of corporate foundation boards, typical composition of the board, legal issues that board members will want to understand, board orientation, establishing meeting protocols, and the interaction between board and staff, among other topics. Appendices include sample by-laws and a bibliography.

\section{Foundation Specific - Independent}

Self-study guide for independent foundation boards. [2nd ed.] Washington, DC: Council on Foundations. 1994. 22 p.

Handbook designed to enhance the governance abilities and practices of independent foundations, using a questionnaire format. Sections cover mission; program interests; board membership, organization, management, and operations; grantmaking; fiduciary responsibilities; and general and individual assessment. Includes user guide.

\section{Foundation Specific - Family}

Coy, Cissie. "Always in the family?". Foundation News vol. 32 (January-February 1991) p. 52-4.

Examines the various compositions of family foundation boards. While some family foundations prefer that all trustees be family members, others find that a few outside voices can enrich the process. A family-only board works best when family members have the time and interest to 
direct the foundation. The seven trustees of the Albert Kunstadter Family Foundation in New York City are all family members who personally supervise annual grantmaking of about $\$ 285,000$. The Kunstadter board has two main advantages: 1) it can maintain close relations with grantees, and 2) it can respond quickly to requests. Family-only boards are well suited to foundations with finely focused grantmaking interests. The Bert and Mary Meyer Foundation in Orlando, Fla. has a two-tier board that allows for community representation while maintaining family control of the organization. Meyer's two-tier board is comprised of three white family members and two blacks, one American Indian, and a Salvadoran. Women make up the majority of the board. The seven board members make policy and grantmaking decisions, but the three family members elect the board and amend the articles and bylaws. Outsiders are also limited to one-year terms. Paul Ylvisaker finds two strong arguments for bringing outsiders onto the board: 1) diversity, and 2) the ability to rise above family concerns. Some family foundations find that giving some authority to advisory committees is a good way to strengthen diversity.

\section{$\underline{\text { Geographic Specific }}$}

Chernoff, David S. Duties and responsibilities of directors and trustees of Illinois private foundations. Chicago, IL: Donors Forum of Chicago. 1997. vii, 35 p.

Amighetti, Leopold. "Responsibilities and liabilities of foundation directors and trustees". Philanthropist/Le Philanthrope vol. 13 (Number 1) 1996 p. 3-28.

Recommendations for board members in Canada.

\section{$\underline{\text { Legal \& Financial }}$}

Craig, John E., Jr. "Governance issues affecting foundation investing". Philanthropy vol. 9 (Spring 1995) p. 14-7, 29.

Edie, John A.; Smith, Lowell S. "Investing in U.S. securities is a violation of your fiduciary duty". Foundation News vol. 34 (November-December 1993) p. 24-30.

Reports on new developments in law, modern investment theory, and current research on foundation investments, that have refined the notion of fiduciary duty. First of a two-part series.

Edie, John A.; Smith, Lowell S. "Let go of your old investment assumptions". Foundation News vol. 35 (January-February 1994) p. $34-9$.

Provides recommendations on new ways foundation governing boards can preserve endowment using modern portfolio management. Second of a two-part series.

Flather, Newell; Maksy, Pamela Labonte. "This Is Your Final Notice." Foundation News \& Commentary, vol. 44 (July-August 2003): p. 30-4.

Fiduciary oversight is a primary responsibility of foundation trustees. This article provides practical advice to foundation board members on safeguarding the funder, and four case studies illustrate potential pitfalls. 
Tools

Boardsmanship [video recording]. Washington, DC: Council on Foundations. 1999. 50:00 minutes.

Workbook and videotape.

Calhoun, Susan. "A helpful look inward". Foundation News vol. 28 (January-February 1987) p. 63-4.

Description of a self-study program developed by the Association of Governing Boards of Colleges and Universities for their trustees and rewritten for use by foundation trustees. The program enables foundation trustees to evaluate and improve their performance. The self-study guide is available in three versions tailored to family, non-family and community foundations. The project is overseen by the Council on Foundations' Director of Information, Carol Hooper.

Clohesy, Stephanie (ed.); Di Leonardi, Rob (ed.); Fierman, Kim (ed.) Foundation in a box. Bethesda, MD: Association of Small Foundations. 2003. 6 vols.

Composed of six volumes: Volume 1: Introduction; Volume 2: Boards; Volume 3: Investments; Volume 4: Tax \& Legal; Volume 5: Grantmaking; and Volume 6: Administration. Various specialists have contributed chapters to the set.

Council on Foundations (comp.) Trustee orientation packet. Unpublished. [1988]. 1 v. (various pagings).

Council on Foundations (comp.) Trustee orientation resource. Washington, DC: Council on Foundations. 1993. i, 108 p.

Draper, Lee. "Don't make a 'hasty retreat'". Foundation News \& Commentary vol. 42 (January-February 2001) p. 32-6.

Explains the advantages of a board retreat, and how to organize the event effectively. A sideboard provides the experience and recommendations from the Flintridge Foundation, a family foundation in Pasadena, CA.

Edie, John A.; Council on Foundations. Directors and officers liability insurance and indemnification : an explanation for foundations. [Rev. ed.] Washington, DC: Council on Foundations. 1993. ii, 37 p.

Arranged in a question and answer format, this booklet provides information on indemnification and directors and officers (D\&O) liability insurance. Also addresses the correct tax treatment of insurance premiums and discusses the main features of the Chubb Group's D\&O liability insurance program, which has been endorsed by the Council on Foundations.

Mintz, Joshua; Cavanaugh, Denise; Pierson, Jane. Self-assessment for foundation boards : user's guide and questionnaire. Washington, DC: National Center for Nonprofit Boards. 2000. 66 p. 
Strauch, Carol. "Getting oriented". Foundation News vol. 31 (September-October 1990) p. 28-33.

Examines the importance of orienting new trustees if foundations want to have effective boards. Certain roles and responsibilities, essential facts about the foundation, and the cultural norms of the organization need to be imparted to new board members. Includes a list of information which is worth including in a board handbook, and selected resources on board training.

\section{OTHER}

\section{General Resources}

Lipton, David A.; Virginia Law Review. Significant private foundations and the need for public selection of their trustees. Reprint. Charlottesville, VA: Virginia Law Review Association. 1978. 54 p.

\section{$\underline{\text { Diversity }}$}

Bryson, Ellen; Parsons, Steve. What foundation boards are saying about diversity. Washington, DC: Council on Foundations. 2003. 13 p.

\section{$\underline{\text { Profiles \& Case Studies }}$}

Osborn, Torie; Ramirez, Margarita. "Grantmaking from the grassroots". Foundation News \& Commentary vol. 43 (May-June 2002) p. 41-2.

A case study focusing on the Liberty Hill Foundation, whose board is primarily community activists.

Williams, Roger M. "Spreading the net". Foundation News vol. 32 (November-December 1991) p. 31-3.

Profiles Wisconsin's Community Foundation for the Fox Valley Region. The foundation's organizers ran an advertisement in the newspaper to find their forty-eight member board of directors.

\section{$\underline{\text { Reports }}$}

Billitteri, Thomas J. "Foundation investment and governance policies detailed in new report". Chronicle of Philanthropy vol. 11 (11 March 1999) p. 36-7. Summarizes the new report "Foundation Management Series", 9th edition, published by the Council on Foundations. The report is detailed in a four-volume series and is based on a 1997 survey of 673 foundations. It contains information about foundation investment practices, board 
composition and compensation policies, finances and management, and benefits and personnel policies.

Foundation governance : the CEO viewpoint. Cambridge, MA: Center for Effective Philanthropy. 2004. 19 p.

This publication provides the results of a survey of CEOs of the largest 250 foundations in the U. S., specifically delving into the CEO-board relationship. Among the findings: about half the trustees receive compensation for their board service.

Moore, Jennifer. "White men still dominate foundation boards". Chronicle of Philanthropy vol. 5 (23 February 1993) p. 47, 50-1.

Reports on the findings in the Council on Foundation's "Foundation Management Report", 7th edition.

Trustee connection : the middle tier. Washington, DC: Women \& Philanthropy. [2000?]. 20

p.

Data was collected from a survey of corporate, community, and independent foundations to determine the diversity--as well as disabilities and sexual preference--among their board members. Compilation of data was followed-up with trustee interviews. Results are presented in tabular and narrative form.

\section{$\underline{\text { Women \& Boards }}$}

Bonavoglia, Angela. The trustee connection : making a difference. New York, NY: Women and Foundations/Corporate Philanthropy. 1994. 36 p.

Presents a detailed account of women foundation trustees, based on in-depth personal interviews with seventeen women trustees of various foundations representing different regions, ages, backgrounds, races, classes, ethnicities, and types of foundations. Provides insight into the workings and thinkings of a seldom-studied but highly influential group. With bibliography and resource list.

Goss, Kristin A.; Women and Foundations/Corporate Philanthropy. "Study finds twenty percent of the trustees of large foundations are women, fourteen percent are members of minority groups". Chronicle of Philanthropy vol. 2 (3 April 1990) p. 1, 16-7.

Reviews a Women and Foundations/Corporate Philanthropy study of seventy-five major foundation boards. Includes tables showing the names of all foundations in each of the three groups, along with number of total trustees, number and percent of women and minority trustees, and ranking.

Greene, Stephen G. "Women gain on foundation staff but not on boards". Chronicle of Philanthropy vol. 2 (4 September 1990) p. 25, 28.

According to this Council on Foundations management study, compiled from data supplied by 723 foundations, there has been an increase of women employed as professionals on the staff of U.S. foundations, but not on their boards of directors. Includes information on salaries by geographic area and type and size of foundation. Other data included in this study: administrative 
expenses in managing the grantmaking activities of foundations; types of investments made by foundations of various sizes; and yearly wages of boards of directors by size of foundations.

Teltsch, Kathleen; Joseph, James A.; Council on Foundations. "At foundations, the voice of women and minorities remains faint. New York Times (7 April 1990)

Examines the issue of racial, ethnic and sexual diversity among the boards of American

foundations.

Women and Foundations/Corporate Philanthropy. Far from done : the challenge of diversifying philanthropic leadership. New York, NY: Women and Foundations/Corporate Philanthropy. 1990. 25 p.

Part of a long-term effort by Women and Foundations/Corporate Foundations to encourage diversity within philanthropy, this report examines the diversity of foundation board composition by race and gender. Report includes an interview with Jean Fairfax (Chair of the Advisory Committee to the Council on Foundation's Pluralism in Philanthropy Project) about diversifying foundation boards, a discussion of the token representation of women on foundation boards, an article on reactions to the survey data on foundation board composition, and case studies on diversifying foundation boards. 